\title{
Hemangiopericytoma of the Parapharyngeal Space: A Diagnostic Challenge
}

\author{
Ithzel Maria Villarreal Jose Garcia Berrocal Beatriz Brea Eva Tejerina \\ Jose Castello Rafael Ramirez-Camacho \\ Hospital Universitario Puerta de Hierro Majadahonda, Madrid, Spain
}

\section{Key Words}

Parapharyngeal space $\cdot$ Hemangiopericytoma $\cdot$ Vimentin $\cdot$ MRI $\cdot$ CT scan

\begin{abstract}
Parapharyngeal space tumors are known for having a difficult approach, misleading diagnosis and for representing a treatment challenge. Hemangiopericytomas account for less than $1 \%$ of all vascular neoplasms and $3 \%$ of all soft tissue sarcomas. Only 14 cases have been reported in the worldwide literature in this location. We present a case of a 44-year-old male who was referred for evaluation. A CT scan and MRI showed a large parapharyngeal mass of a possible salivary gland origin. The patient underwent a lateral cervicotomy associated with a transparotid-transmandibular approach, obtaining a vimentin-positive immunostaining tumor defining the diagnosis. The accurate management and prognosis of this type of neoplasm are provided by the definite diagnosis obtained by a correct histopathologic assessment. A high clinical suspicion is essential.

(C) 2014 S. Karger AG, Basel
\end{abstract}

\section{Introduction}

The parapharyngeal space located deep within the cervical region is divided in the prestyloid and retrostyloid compartments. Most of the salivary gland neoplasms are located in the prestyloid space, and neurogenic tumors account for most of the retrostyloid masses [1]. Tumors in this area are known for having a difficult approach, misleading diagnosis and for representing a treatment challenge. The clinical course is usually asymptomatic even when tumors reach large sizes. Some symptoms may include dysphagia, otalgia, dyspnea and 


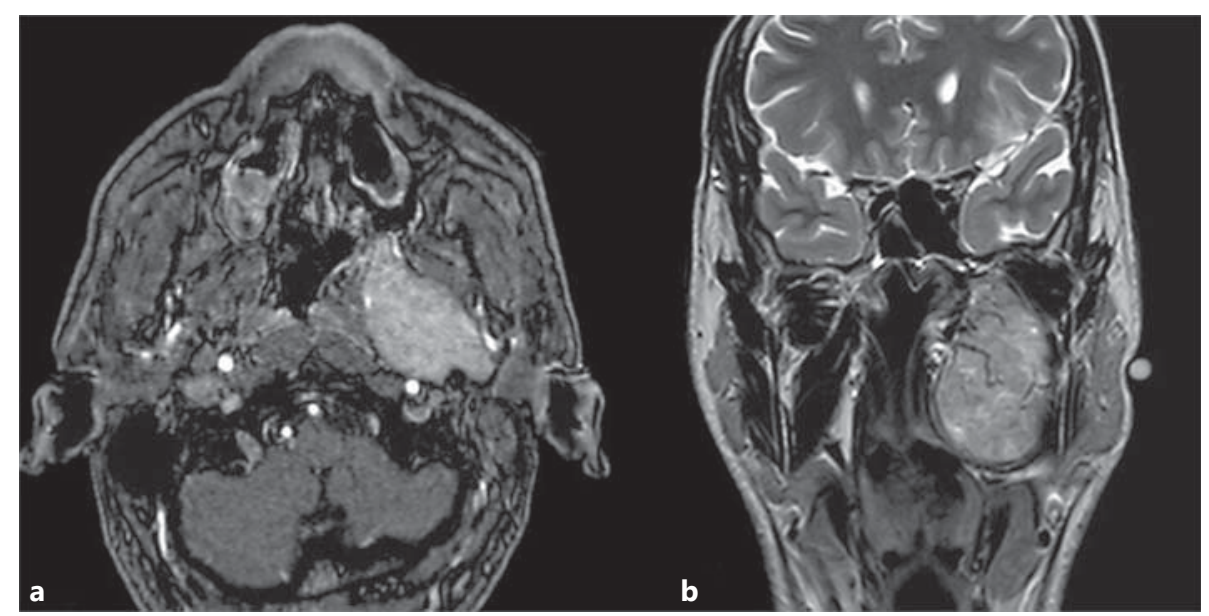

Fig. 1. Axial T1 slice with gadolinium (a) and T2 coronal slice (b) showing a large mass $(5.7 \times 4.6 \times 2.8 \mathrm{~cm})$ occupying the prestyloid parapharyngeal space, which is hypointense in T1 and hyperintense in T2. Intense enhancement after intravenous gadolinium administration is seen, which implies high vascularization.

foreign body sensation [2]. Imaging studies are essential for evaluation due to the limitations of physical examination.

Hemangiopericytoma (HPC) is a vascular tumor that accounts for less than $1 \%$ of all vascular neoplasms and 3\% of all soft tissue sarcomas [3]. In the head and neck area, the most common sites include the jaw, parotid gland, nasal cavity, orbit, masticator space, paranasal sinuses and the jugular foramen [3].

\section{Case Report}

A 44-year-old male with no significant medical history was referred for the evaluation of a parapharyngeal and left cranial base asymptomatic tumor that was found incidentally during a sleep apnea study. A cervical MRI revealed a parapharyngeal mass of $5.7 \times 4.6 \times 2.8 \mathrm{~cm}$ of a possible salivary gland origin, with intense enhancement with gadolinium that had no intracranial involvement (fig. 1). The physical examination revealed a painless, nonpulsatile mass that displaced and enlarged the left naso-oropharyngeal wall. During a previous tracheotomy, a lateral cervicotomy associated with a transparotid and transmandibular approach was performed. The postoperative evolution was satisfactory and uneventful. The only complication observed was a 2-month paresis of a marginal branch of the facial nerve. Seven months later, an MRI revealed complete tumoral resection.

The histopathologic result revealed a highly cellular tumor, mildly pleomorphic, with round and oval to spindle cells with no atypia, very tightly packed in an intimate relationship with a profuse vascular network located in a collagenous stroma. Large vessels had a characteristic 'staghorn' morphology. Immunohistochemistry showed strong positivity with vimentin and CD34 and was negative for cytokeratins, EMA, S100 and others (fig. 2). Vimentin is the only marker expressed consistently in HPC [3].

\section{Discussion}

HPC is a very rare type of neoplasm, and when located in the parapharyngeal space, it becomes even more uncommon. Only a few cases have been reported previously in the worldwide literature (table 1). There is an equal incidence in both sexes, and the appearance 


\begin{tabular}{l|l}
\hline ORL $2014 ; 76: 76-80$ & \\
\hline DOI: $10.1159 / 000360480$ & $\begin{array}{l}\text { @ } 2014 \text { S. Karger AG, Basel } \\
\text { www.karger.com/orl }\end{array}$ \\
\hline
\end{tabular}

Villarreal et al.: Hemangiopericytoma of the Parapharyngeal Space: A Diagnostic Challenge

Table 1. Cases reported in the literature

\begin{tabular}{ll}
\hline & First author, year \\
\hline Case 1 & Fountoulakis [2], 2011 \\
Case 2 & Fareed [3], 2012 \\
Case 3 & Dimri [5], 2010 \\
Case 4 & Vo [10], 2007 \\
Case 5 & Gierek, 2000 \\
Case 6 & Llorente [7], 1999 \\
Case 7 & Robb [4], 1987 \\
Case 8 & Wakisaka [8], 2009 \\
Case 9 & Kairemo [discussed in 7], 1991 \\
Case 10 & Ozdzinskia , 1995 \\
Case 11 & Shaia [6], 2006 \\
Case 12 & McIIrath [discussed in 7], 1963 \\
Case 13 & McMaster [discussed in 7], 1975 \\
Case 14 & Rosignoli [discussed in 7], 1993 \\
\hline \multicolumn{2}{c}{ a Taken from two abstracts in English of articles written in Polish, } \\
which report 2 cases of hemangiopericytomas of the parapharyngeal \\
space; not included in the reference list. \\
\hline
\end{tabular}
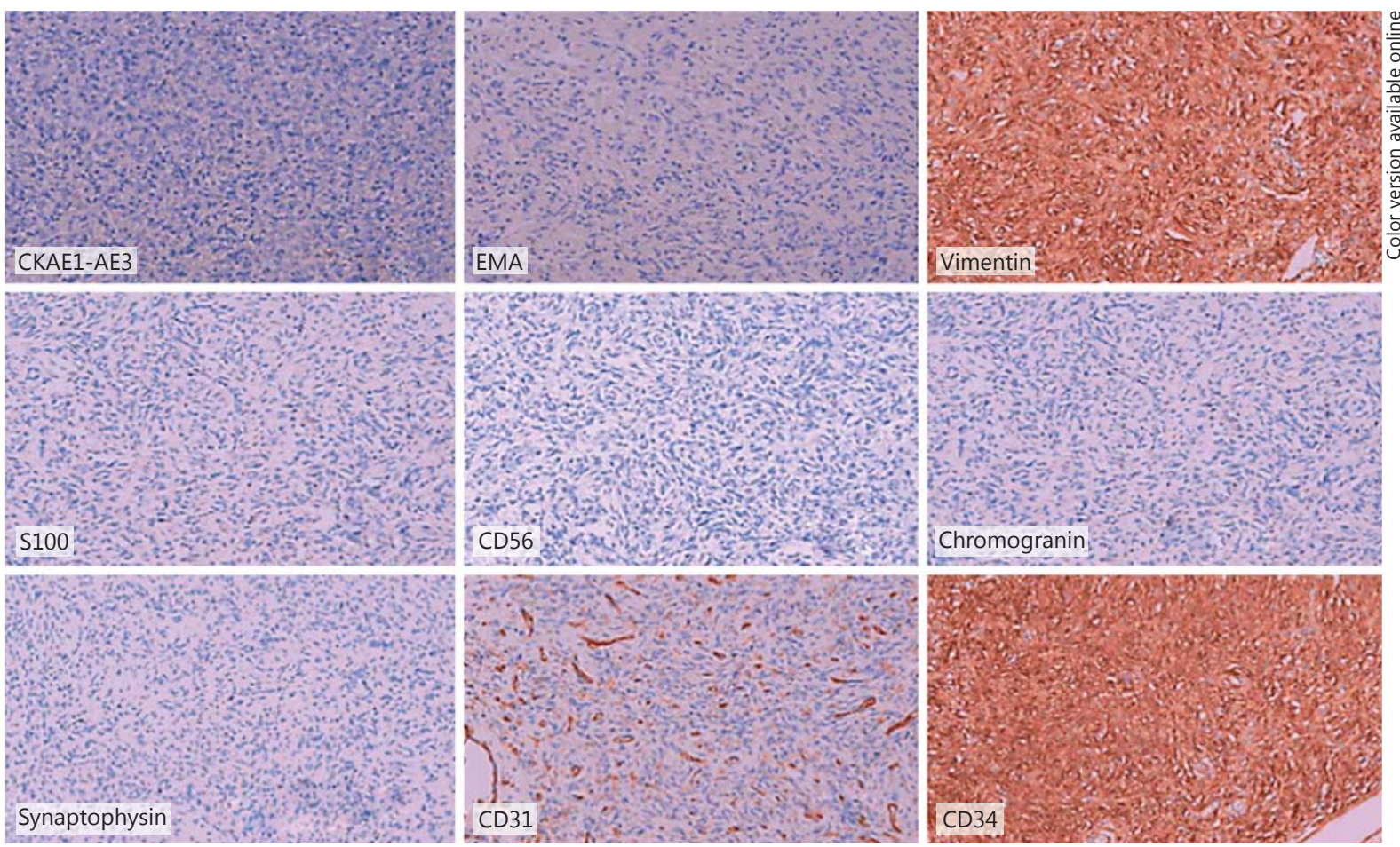

Fig. 2. Immunohistochemical profile of the neoplasm.

peak occurs in the fifth and the sixth decade of life [2,3]. Distant metastasis rates range from 18 to $69 \%$ [3]. Some studies have mentioned trauma, hypertension and long-term steroid use to be possible etiologies. In our case, they were dismissed [3].

The initial clinical suspicion may be given by symptoms due to the compression of surrounding structures or by its external appearance [4]. It has been reported that all masses 
Villarreal et al.: Hemangiopericytoma of the Parapharyngeal Space: A Diagnostic Challenge

Table 2. Radiological features of the tumors in the parapharyngeal space

\begin{tabular}{|c|c|c|c|c|c|}
\hline & Morphology & CT & MR:T1 & MR:T2 & $\begin{array}{l}\text { MR:contrast- } \\
\text { enhanced T1 }\end{array}$ \\
\hline $\begin{array}{l}\text { Prestyloid } \\
\text { parapharyngeal } \\
\text { space } \\
\text { Second branchial cleft } \\
\text { cyst }\end{array}$ & Well defined & $\begin{array}{l}\text { Uniloculated } \\
\text { cystic lesion }\end{array}$ & Hypointense & Hyperintense & No \\
\hline Cystic lymphangioma & Well defined & $\begin{array}{l}\text { Multiloculated } \\
\text { cystic lesion }\end{array}$ & Hypointense & Hyperintense & No \\
\hline $\begin{array}{l}\text { Minor or ectopic } \\
\text { salivary gland tumors }\end{array}$ & $\begin{array}{l}\text { Well-defined } \\
\text { spherical mass }\end{array}$ & $\begin{array}{l}\text { Hyperdense } \\
\text { well-defined } \\
\text { lesion }\end{array}$ & Hypointense & Hyperintense & $\begin{array}{l}\text { Usually homogeneous } \\
\text { enhancement }\end{array}$ \\
\hline Neurogenic tumors & $\begin{array}{l}\text { Well-defined } \\
\text { spherical mass }\end{array}$ & $\begin{array}{l}\text { Hyperdense } \\
\text { well-defined } \\
\text { lesion }\end{array}$ & Hypointense & Hyperintense & $\begin{array}{l}\text { Intense homogeneous } \\
\text { enhancement }\end{array}$ \\
\hline $\begin{array}{l}\text { Infiltrative masses: } \\
\text { soft tissue sarcomas }\end{array}$ & Ill defined & $\begin{array}{l}\text { Slightly ill-defined } \\
\text { lesions }\end{array}$ & $\begin{array}{l}\text { Hypointense involving } \\
\text { several adjacent spaces }\end{array}$ & $\begin{array}{l}\text { Hypointense } \\
\text { ill-defined } \\
\text { lesion }\end{array}$ & $\begin{array}{l}\text { Variable } \\
\text { heterogeneous } \\
\text { enhancement }\end{array}$ \\
\hline $\begin{array}{l}\text { Postyloid } \\
\text { parapharyngeal } \\
\text { space } \\
\text { Neurogenic tumors }\end{array}$ & $\begin{array}{l}\text { Well-defined } \\
\text { spherical mass }\end{array}$ & $\begin{array}{l}\text { Hyperdense } \\
\text { well-defined } \\
\text { lesion }\end{array}$ & Hypointense & Hyperintense & $\begin{array}{l}\text { Intense homogeneous } \\
\text { enhancement }\end{array}$ \\
\hline Paragangliomas & $\begin{array}{l}\text { Well-defined } \\
\text { oval mass }\end{array}$ & $\begin{array}{l}\text { Hyperdense } \\
\text { well-defined } \\
\text { lesion }\end{array}$ & Hypointense & Hyperintense & $\begin{array}{l}\text { Intense homogeneous } \\
\text { enhancement }\end{array}$ \\
\hline
\end{tabular}

bulging in the oropharyngeal area were larger than $3 \mathrm{~cm}$, and $20 \%$ of them were found incidentally during routine physical examinations or while the patient was undergoing tests or follow-ups for other pathologies. The clinical behavior of HPC is unpredictable, and it is usually described as a painless enlarging mass $[2,4,5]$. Vascular signs may include telangiectasiae, pulsation or audible bruit [4]. Hypoglycemia, hypertension, hypokalemia secondary to hyperreninemia and cardiac failure are some systemic effects that have also been described in previous studies [4].

The diagnosis relies on the histological examination. Findings such as uniform vascular spaces surrounded by densely packed cells and the characteristic reticulin 'staghorn' pattern are typical of HPC [4-6]. In the WHO classification of soft tissue tumors, benign and malignant HPC have been recognized [4]. Criteria of malignancy [4] are presence of necrosis, high cellular density, presence of pleomorphic or immature cells, hemorrhage foci, high mitotic activity (more than 4/10) and a large macroscopic mass (more than $5 \mathrm{~cm}$; some studies 6.5 $\mathrm{cm})[2,3,6]$. In our case, it was considered a mass with low malignant potential.

CT scanning and MRI may provide useful preoperative information about tumor features, extension, relationship with surrounding structures and osseous erosions (table 2). The use of contrast ascertains the vascularity of the tumor. MRI is essential for scheduling the surgical plan and should be considered the 'gold standard' for the study of this tumor. Nevertheless, imaging is not specific and has no pathognomonic findings $[2,5$, $7,8]$. Fine-needle-aspiration cytology or biopsy is not advised in this type of tumor due to the high risk of bleeding [7]. 
Some differential diagnoses include glomus tumor, hemangiomas, histiocytomas, angiosarcoma, schwannoma and others [2, 3, 9]. It is important to clarify that in our patient, the initial suspicion was a pleomorphic adenoma of a minor salivary gland. For preoperative differential diagnosis, a conventional angiography may be considered as well as if embolization is part of the plan $[2,5,7]$.

A radical excision is the treatment of choice [3]. Radiotherapy should be considered in recurrent tumors, cases of incompletely excised lesions and tumors with malignant features $[2,5]$. Chemotherapy has its basic role in distant metastatic disease. If a complete resection is made, there is a $100 \%$ median survival rate at 60 months $[3,10]$.

\section{Conclusion}

The accurate management and prognosis of this type of neoplasm are provided by the definite diagnosis obtained by a correct histopathologic assessment. The biological behavior of these tumors is quite peculiar, for there have been clinical reports of metastasis found even in benign, nonmitotic hemangiopericytomas.

A thorough imaging evaluation must be performed prior to surgery. Large tumors with significant vascularity should be evaluated with angiography, and preoperative embolization may be taken into consideration. An attempt for a surgical radical resection must always be intended. Long-term follow-up is very important due to its imprecise nature and previously reported late recurrences.

\section{References}

1 Bailey B, Shields G: Parapharyngeal space tumors. October 9, 2002. www.utmb.edu/otoref/grnds/parapharyngeal-021009/m-parapharyngeal-021009.htm (accessed April 14, 2013).

- 2 Fountoulakis EN, Papadaki E, Panagiotaki I, et al: Primary haemangiopericytoma of the parapharyngeal space: an unusual tumour and review of the literature. Acta Otorhinolaryngol Ital 2011;31:194-198.

- 3 Fareed M, Al Amro A, Akasha R, et al: Parapharyngeal space hemangiopericytoma treated with surgery and postoperative radiation - a case report. Head Neck Oncol 2012;4:10.

4 Robb P, Singh S, Hartley R, et al: Malignant haemangiopericytoma of the parapharyngeal space. Head Neck Surg 1987; 9:179-183.

5 Dimri K, Nimbran VK, Kumar A, et al: Haemangiopericytoma of the parapharyngeal space: an uncommon tumor in an unusual site. Indian J Cancer 2010;47:86-87.

- 6 Shaia W, Bojrab D, Babu S, et al: Lipomatous hemangiopericytoma of the skull base and parapharyngeal space. Otol Neurotol 2006;27:560-563.

- 7 Llorente J, Suárez C, Ablanedo P, et al: Haemangiopericytoma of the parapharyngeal space. Otolaryngol Head Neck Surg 1999;120:531-533.

- 8 Wakisaka N, Kondo S, Murono S, et al: A solitary fibrous tumor arising in the parapharyngeal space, with MRI and FDG-PET findings. Auris Nasus Larynx 2009;36:367-371.

9 Espat NJ, Lewis JJ, Leung D, et al: Conventional hemangioperycitoma modern analysis of outcome. Cancer 2002; $95: 1746-1751$.

10 Vo QT, Wolf JA, Turner JW, et al: Solitary fibrous tumor of the parapharyngeal space. Ear Nose Throat J 2007; $86: 502-505$. 